\title{
Correction to: Context dependent variation in corticosterone and phenotypic divergence of Rana arvalis populations along an acidification gradient
}

\author{
Jelena Mausbach ${ }^{1,2^{*}}$, Anssi Laurila $^{3}$ and Katja Räsänen ${ }^{1,2,4^{*}}$ (1)
}

\section{Correction to: BMC Ecology and Evolution (2022) 22:11} https://doi.org/10.1186/s12862-022-01967-1

Following the publication of the original article [1], we were notified that the authors' first and last names have been swapped.

Originally published names: Mausbach Jelena, Laurila Anssi and Räsänen Katja.

Corrected names: Jelena Mausbach, Anssi Laurila and Katja Räsänen.

The original article has been corrected.

\section{Author details}

'Department of Aquatic Ecology, Eawag, Ueberlandstrasse 133, 8600 Duebendorf, Switzerland. ${ }^{2}$ Institute of Integrative Biology, ETH Zurich, Universitätstrasse 16, 8092 Zurich, Switzerland. ${ }^{3}$ Animal Ecology/Department of Ecology and Genetics, Evolutionary Biology Centre, Uppsala University, Norbyvägen 18D, 75236 Uppsala, Sweden. ${ }^{4}$ Department of Biological and Environmental Science, University of Jyväskylä, Survontie 9C, 40014 Jyväskylä, Finland.

Published online: 07 March 2022

\section{Reference}

1. Mausbach J, Laurila A, Räsänen K. Context dependent variation in corticosterone and phenotypic divergence of Rana arvalis populations along an acidification gradient. BMC Ecol Evol. 2022;22:11. https://doi.org/10. 1186/s12862-022-01967-1.

\section{Publisher's Note}

Springer Nature remains neutral with regard to jurisdictional claims in published maps and institutional affiliations.

(c) The Author(s) 2022. Open Access This article is licensed under a Creative Commons Attribution 4.0 International License, which permits use, sharing, adaptation, distribution and reproduction in any medium or format, as long as you give appropriate credit to the original author(s) and the source, provide a link to the Creative Commons licence, and indicate if changes were made. The images or other third party material in this article are included in the article's Creative Commons licence, unless indicated otherwise in a credit line to the material. If material is not included in the article's Creative Commons licence and your intended use is not permitted by statutory regulation or exceeds the permitted use, you will need to obtain permission directly from the copyright holder. To view a copy of this licence, visit http://creativecommons.org/licenses/by/4.0/. The Creative Commons Public Domain Dedication waiver (http://creativeco mmons.org/publicdomain/zero/1.0/) applies to the data made available in this article, unless otherwise stated in a credit line to the data. 